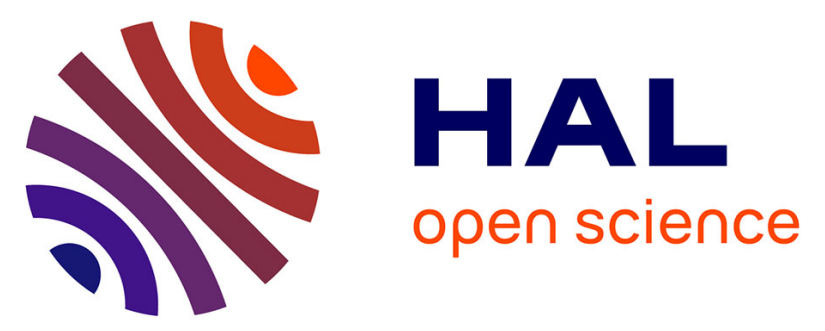

\title{
Nature-based Solutions: New Influence for Environmental Management and Research in Europe Nature-based Solutions, an Emerging Term
}

Hilde Eggermont, Estelle Balian, José Manuel N. Azevedo, Victor Beumer, Tomas Brodin, Joachim Claudet, Bruno Fady, Martin Grube, Hans Keune, Penelope Lamarque, et al.

\section{To cite this version:}

Hilde Eggermont, Estelle Balian, José Manuel N. Azevedo, Victor Beumer, Tomas Brodin, et al.. Nature-based Solutions: New Influence for Environmental Management and Research in Europe Nature-based Solutions, an Emerging Term. GAIA - Ecological Perspectives for Science and Society, 2015, 24 (4), p. 243-248. 10.14512/gaia.24.4.9 . hal-01245631

\section{HAL Id: hal-01245631 \\ https://hal-univ-perp.archives-ouvertes.fr/hal-01245631}

Submitted on 17 Dec 2015

HAL is a multi-disciplinary open access archive for the deposit and dissemination of scientific research documents, whether they are published or not. The documents may come from teaching and research institutions in France or abroad, or from public or private research centers.
L'archive ouverte pluridisciplinaire HAL, est destinée au dépôt et à la diffusion de documents scientifiques de niveau recherche, publiés ou non, émanant des établissements d'enseignement et de recherche français ou étrangers, des laboratoires publics ou privés. 


\section{Nature-based Solutions: New Influence for Environmental Management and Research in Europe}

\begin{abstract}
Greening roofs or walls to cool down city areas during summer, to capture storm water, to abate pollution, and to increase human well-being while enhancing biodiversity: nature-based solutions (NBS) refer to the sustainable management and use of nature for tackling societal challenges. Building on and complementing traditional biodiversity conservation and management strategies, NBS integrate science, policy, and practice and create biodiversity benefits in terms of diverse, well-managed ecosystems.
\end{abstract}

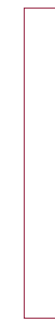

Hilde Eggermont, Estelle Balian, José Manuel N. Azevedo, Victor Beumer, Tomas Brodin, Joachim Claudet, Bruno Fady, Martin Grube, Hans Keune, Penelope Lamarque, Katrin Reuter, Matt Smith, Chantal van Ham, Wolfgang W. Weisser, Xavier Le Roux

Nature-based Solutions: New Influence for Environmental Management and Research in Europe | CAIA 24/4 (2015): 243-248 Keywords: biodiversity, ecosystem services, research programming, social-ecological systems, societal challenges, sustainable management

\section{Nature-based Solutions, an Emerging Term}

It is now widely recognized that human activities have reached a level that could result in abrupt and, in some cases, irreversible environmental changes detrimental to human development (Steffen et al. 2015). Societies face increasing challenges such as climate change, jeopardized food security and water resource provision, and an enhanced disaster risk.

One approach to answer these challenges is to increasingly rely on technological strategies, which are designed and managed to be as simple, replicable and predictable as possible (Hoffert et al. 2002). For instance, physico-chemical biofiltration processes are used to purify air and water at large scales in most countries, in particular in the northern hemisphere. An alternative approach is to manage the (socio-)ecological systems in a comprehensive approach in order to sustain and potentially increase the delivery of the ecosystem services (ES) to humans. ${ }^{1}$

The second approach recognizes the complexity of socio-ecological systems and the fact that they are dynamic, leaving room

1 In this paper, we refer to ES as the direct and indirect contributions of ecosystems to human well-being (Costanza et al. 1997, Millennium Ecosystem Assessment 2005).

2 For instance, ecosystem-based approaches are increasingly promoted for climate change adaptation and mitigation (Cowan et al. 2010, Naumann et al. 2011, Burch et al. 2014) by organisations like United Nations Environment Programme (UNEP) and non-governmental organisations such as The Nature Conservancy. Similarly, green infrastructure refers to an "interconnected network of green spaces that conserves natural systems and provides assorted benefits to human populations" (Benedict and McMahon 2006). for self-reorganization and mutability and associated resistance and resilience capacities (Garmestani and Benson 2013). In this context, nature-based solutions (NBS) have recently been put forward by practitioners (in particular the International Union for Nature Conservation, IUCN) and quickly thereafter by policy (European Commission), referring to the sustainable use of nature in solving societal challenges.

While ES are often valued in terms of immediate benefits to human well-being and economy, NBS focus on the benefits to people and the environment itself, to allow for sustainable solutions that are able to respond to environmental change and hazards in the long-term. NBS go beyond the traditional biodiversity conservation and management principles by "re-focusing" the debate on humans and specifically integrating societal factors such as human well-being and poverty alleviation, socio-economic development, and governance principles.

In this sense, NBS are strongly connected to ideas such as natural systems agriculture (Jackson 2002), natural solutions (Dudley et al. 2010), ecosystem-based approaches (Cowan et al. 2010), green infrastructures (Benedict and McMahon 2006), and ecological engineering (Borsje et al. 2011). ${ }^{2}$

Contact: Dr. Hilde Eggermont | Belgian Biodiversity Platform | Royal Belgian Institute for Natural Sciences | Vautierstraat 29 | 1000 Brussels | Belgium | Tel.: +3226274318 | E-Mail: h.eggermont@biodiversity.be

(c) 2015 H. Eggermont et al.; licensee oekom verlag. This is an Open Access article distributed under the terms of the Creative Commons Attribution License (http://creativecommons.org/licenses/by/3.0), which permits unrestricted use, distribution, and reproduction in any medium, provided the original work is properly cited. 
The concept of ecological engineering may be closest to NBS (at least types 2 and 3 below), though it has different definitions (Mitsch 2012). In particular, Barot et al.(2012) indicate that the goal of ecological engineering is to develop more sustainable practices informed by ecological knowledge with the aim to 1. protecting and 2. restoring ecological systems, 3. modifying ecological systems to increase the quantity, quality and sustainability of particular services they provide, or 4. building new ecological systems that provide services that would otherwise be provided through more conventional engineering based on non-renewable resources. ${ }^{3}$

The term "nature-based solutions" was first used in the late 2000s (MacKinnon et al. 2008, Mittermeier et al. 2008) in the context of finding new solutions to mitigate and to adapt to climate change effects whilst simultaneously protecting biodiversity and improving sustainable livelihoods. The IUCN referred to NBS in a position paper for the United Nations Framework Convention on Climate Change (IUCN 2009), after which the term has been quickly taken up by policy, viewing NBS as an innovative mean to create jobs and growth part of a green economy. Currently, the European Commission is developing a EU research and innovation policy on NBS in the context of its Horizon 2020 Framework Programme (European Commission 2015), with the aim to position Europe as a world leader in this field.

\section{Many Voices, One Term}

The NBS idea has barely been evaluated by the scientific community (but see MacKinnon and Hickey 2009, MacKinnon et al. 2011), and different stakeholders view NBS from different perspectives. For instance, IUCN (2012) stresses that they "can deliver effective solutions to major global challenges, such as climate regulation, using nature while providing biodiversity benefits in terms of diverse, well-managed ecosystems and respecting and reinforcing communities' rights over natural resources". This framing puts biodiversity and local human communities at the heart of NBS. In the context of the on-going political debate on jobs and growth (main drivers of the current EU policy agenda), the European Commission underlines that NBS can transform environmental and societal challenges into innovation opportunities, by turning natural capital into a source for green growth and sustainable development. For the commission, NBS are sustainable measures that aim to simultaneously meet environmental, societal and economic objectives, which should help maintain and enhance natural capital (European Commission 2015). This framing puts economy and social assets at the heart of NBS while sustaining environmental conditions. In any case, NBS are often seen as a concept,

3 Terms such as "ecosystem restoration" (return of an ecosystem to a close approximation of its condition prior to a disturbance or period of specific management) are often seen as part of ecological engineering (National Research Council 1992). The same applies for "agro-ecology" which delineates the ecological principles necessary to develop sustainable agricultural production systems (Altieri 1989). and more likely a flagship term, that can provide incentives for governments, institutions, business and citizens to develop innovative ways to integrate natural capital in policies and planning, and to maintain or increase biodiversity and human well-being (European Commission 2015).

With this paper, we do not intend to provide an in-depth review of all concepts related to NBS, nor to nail down a strict definition. Rather, we aim to sharpen the term, in particular by proposing a typology of NBS, and reflect on its added value with respect to existing terms and concepts, its possible drawbacks in case of misuse, and perceived future challenges for research and management. As such, we hope to spur further discussion, and contribute to sharpening the term allowing for a better evaluation of its true potential.

\section{A Proposed Typology}

We propose a typology characterizing NBS along two gradients (figure 1): 1. "How much engineering of biodiversity and ecosystems is involved in NBS?", 2. "How many ecosystem services and stakeholder groups are targeted by a given NBS?". Due to the ES trade-offs that likely exist (Howe et al. 2014), we hypothesize that most often, the higher the number of services and stakeholder groups is targeted, the lower the capacity to maximize the delivery of each service and simultaneously fulfill the specific needs of all stakeholder groups will be. As such, there are three types of NBS:

- Type 1 consists of no or minimal intervention in ecosystems, with the objectives of maintaining or improving the delivery of a range of ES both inside and outside of these preserved ecosystems. Examples include the protection of mangroves in coastal areas to limit risks associated to extreme weather conditions and to provide benefits and opportunities to local populations; and the establishment of marine protected areas to conserve biodiversity within these areas while exporting biomass into fishing grounds (Grorud-Colvert et al. 2014). This type of NBS is connected to, e. g., the concept of biosphere reserves incorporating core protected areas for nature conservation and buffer and transition areas where people live and work in a sustainable way.

- Type $\mathbf{2}$ corresponds to the definition and implementation of management approaches that develop sustainable and multifunctional ecosystems and landscapes (extensively or intensively managed), which improves the delivery of selected ES compared to what would be obtained with a more conventional intervention. Examples include innovative planning of agricultural landscapes to increase their multifunctionality; and approaches for enhancing tree species and genetic diversity to increase forest resilience to extreme events. This type of NBS is strongly connected to concepts like natural systems agriculture (Jackson 2002), agro-ecology (Altieri 1989), and evolutionary-orientated forestry (Lefèvre et al. 2014).

- Type 3 consists of managing ecosystems in very intrusive ways or even creating new ecosystems (e.g., artificial ecosystems with 


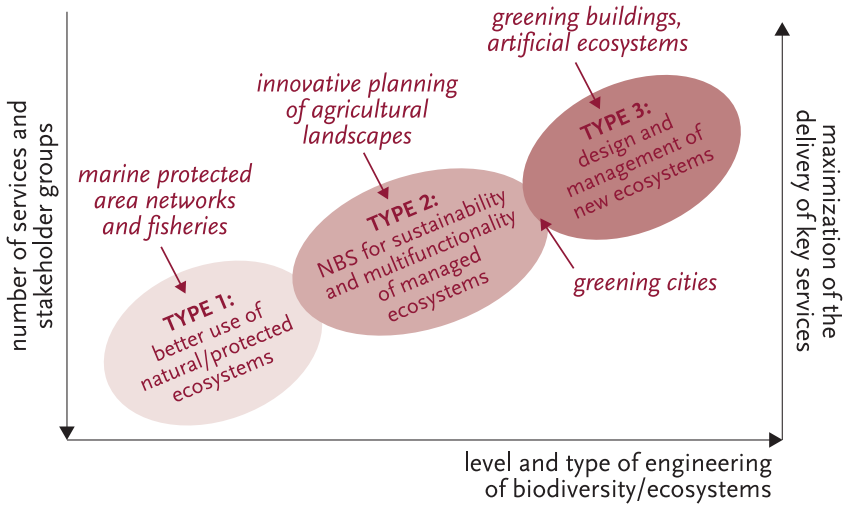

FIGURE 1: Schematic representation of the range of nature-based solutions (NBS) approaches. Three main types of NBS are defined, differing in the level of engineering or management applied to biodiversity and ecosystems (x-axis), and in the number of services to be delivered, the number of stakeholder groups targeted, and the likely level of maximization of the delivery of targeted services (y-axis). Some examples of NBS are located in this schematic representation. Note that the $y$-axes could be shifted, and that type 3 cannot be viewed as "better" than type 1, the three types being complementary.

new assemblages of organisms for green roofs and walls to mitigate city warming and clean polluted air). Type 3 is linked to concepts like green and blue infrastructures ${ }^{4}$ (Benedict and McMahon 2006) and objectives like restoration of heavily degraded or polluted areas. Within this type, novel approaches such as animal-aided design (Hauck and Weisser 2015) are currently being explored to bridge the gap between biodiversity conservation and landscape architecture.

Type 1 fully fits with the way IUCN frames NBS. Types 2 and 3 would also fit with this definition providing that they should contribute to preserving biodiversity and managing or restoring ecosystems sustainably while delivering a range of ES. In the case of agro-ecosystems or inner city green spaces, e. g., it would be important to consider ecological complexity and connection with surrounding ecosystems to provide biodiversity benefits. Type 2 and moreover type 3 are often exemplified by the European Commission for turning natural capital into a source for green growth and sustainable development.

The boundary between these three types is obviously not clearcut. Hybrid solutions exist along this gradient both in space and time. For instance, at landscape scale, mixing protected and managed areas could be needed to fulfill multifunctionality and sustainability goals. Similarly, a constructed wetland can be developed as a type 3 but, when well established, may subsequently be preserved and surveyed as a type 1 .

Outlier examples (that would plot upper-left and bottom-right) are likely rare. Pristine ecosystems, like taiga, have many roles at local and global scale (like water and climate regulation, support to livelihoods of local populations, etc.), and may therefore not be restricted to a narrow range of stakeholders. Similarly, although abilities to manage complex ecosystems will continue to increase over the coming decades, the design of artificial ecosystems will likely target only a few ES and have to tackle ES trade-off.

\section{Opportunities and Risks Associated to NBS}

\section{What NBS are, or are not}

While we advocate that the open nature of the term NBS can favor its success, we contend that it is important to specify which solutions should and should not be considered as NBS. We illustrate this with the development of green roofs and walls in cities. Having in mind the sole objective of developing green surfaces in urban areas to mitigate the effects of global warming, green roofs or walls could be created using, e. g., clones from one or very few plant species, regardless of their biogeographical distribution. Such new structures would hardly contribute to increase biodiversity and the delivery of other ES. This may also lead to a poor resistance and resilience to future extreme events, increased management costs, and risk of biological invasions. Furthermore, without a coordinated approach at the city scale, firms would likely design green buildings in a case-by-case approach with a very uncertain effectiveness at city scale. Such an approach, which largely misses out on the objectives of sustainability, increased biodiversity, and effectiveness at relevant scale (here the city), would not fit the NBS framing. Similarly, rain gardens designed to manage storm water runoff that pay little reference to what plants are used and to other ES, fall short of NBS. In contrast, within an urban planning approach at the city scale, a range of species could be selected for green roofs or walls based on their biogeography and key functional traits (Lundholm et al. 2015), which would address multiple goals such as cooling during summer, storm water capture, pollution abatement, increased human well-being, biodiversity enhancement, and better resilience to future hazards, while adopting adequate governance to properly tackle the issue at city scale (figure 2, p. 247). Such approaches would fit the NBS term. NBS thus broadens the ES framework, promoting and better relying on biological diversity to increase the resistance and resilience of social-ecological systems to global changes and extreme or unexpected events and the delivery of a range of ES.

\section{Calling for innovative NBS should not imply loosing track of existing ones}

NBS are often referred to as innovative, but they should not include exclusively "new" solutions. Whilst the NBS concept offers new opportunities and brings added-value, it also encompasses existing ideas and requires inclusion of lessons from the past. Local and traditional knowledge should also be considered when exploring NBS. Traditional management systems (e. g., for agriculture, forestry, aquaculture, fishing) and their principles should be re-assessed in light of NBS criteria, as they often include sustainable, locally-adapted and biodiversity-enhancing practices. For example, engineered biodiverse pastures developed in Portugal in the 1960s and 1970s provide higher yields of better quality forage, significantly increase sustainable stocking rates, and have mul-

\footnotetext{
4 Green or blue infrastructures should solve urban and climatic challenges by building with nature.
} 
tiple environmental co-benefits (Teixeira et al. 2015). This could be a typical NBS unrecognized as such so far.

\section{NBS should exploit win-win situations but will have to cope with trade-offs and uncertainties}

NBS should account for multiple interests (in particular environmental, societal, and economic ones) and promote sustainability. Yet, there will be few win-win situations where all goals are simultaneously met. Documenting and analyzing the possible synergies and trade-offs between ES and stakeholders' expectations will therefore be at the heart of identifying and implementing NBS. In addition, stakeholders and policy makers must remain aware of the complexities and uncertainties that surround NBS. Assessing the risks associated with a given NBS should be compulsory and alternative solutions should be envisaged, looking at the potential impacts through time and space, and accounting for future environmental changes. Otherwise, NBS could generate problems instead of solutions (e. g., species introduced for pest control can become invasive, if corresponding controls are lacking).

\section{NBS could help meet various ethical, intellectual and relational challenges}

NBS clearly build on, and share aspects with other concepts, approaches and tools, but might be more holistic and have more potential to support environmental sustainability. More specifically, the NBS approach may help meet three types of challenges - ethical, intellectual, relational - that other concepts have not completely addressed so far (Jones 2011; but see Hauck et al. 2013).

Ethical challenges arise at two different levels: NBS are 1. a human-centered utilitarian concept, and 2. include other knowledge systems beyond modern science (i.e., indigenous and local knowledge). As the NBS term clearly refers to societal challenges (ontological dimension), problems defined by humans (epistemic dimension), and the sustainable use of nature (practical dimension), there is no doubt that the concept is anthropocentric as are other current concepts such as ES. The debate on anthropocentric and bio- or ecocentric (assuming an intrinsic value of living beings, entire ecosystems, or the biosphere) views has been at the heart of the discussions on the Intergovernmental Platform for Biodiversity and Ecosystem Services (IPBES) conceptual framework (Diaz et al. 2015) and the discussion on "the new conservation" (Kareiva 2014); we will not start it again here. We advocate that NBS might help to demonstrate that these two views can be complementary, leading to successful approaches to promote biodiversity. The second ethical challenge relates to the plurality of value and knowledge systems that exist among different cultures regarding human-nature interactions. This plurality of views has to be acknowledged and integrated while developing and assessing NBS, and stakeholder participation has to be ensured. NBS have the potential to solve or avoid conflicts here, because they aim at dealing with concrete problems often at a local level. Moreover, research has shown that a mismatch exists between ES approaches and governance needs (Primmer and Furman 2012) and that transdisci- plinary approaches are more likely to achieve effective change on the ground (BIOMOT 2014).

The intellectual challenge requires those coming from various scholastic traditions (ecosystem science and ecology, conservation and restoration, forestry and agronomy, sociology, economics, architecture, etc.) to respectively identify and fuse their key principles into a coherent, useful set that is comprehensible and accessible to all. The nature of NBS could help with providing the critical intellectual mass and rapid cross-fertilization of ideas needed for reaching this ambition. Moreover, there is a need to promote research models where applied and fundamental sciences are not opposed, thereby facilitating transdisciplinarity (Barot et al. 2015).

The relational challenge is strategic. Being promoted by practitioners and policy makers rather than scientists (unlike, e. g., ES: Gómez-Baggethun et al. 2009), one added-value of the NBS term could be that it is easier to grasp by non-technical audiences and key societal partners (business, policy, education, and practitioners), and hence could promote the stakeholder model of research (Barot et al. 2015), receive wider support, and result in systemic solutions rather than sectorial ones. Although many practitioners and scientists working in traditional fields such as agriculture, forestry and aquaculture are genuinely concerned by sustainability issues, they often have difficulties integrating scientific ecological knowledge and turning towards drastically new practices (Neßhöver et al. 2013, Lewinsohn et al. 2015). Work on NBS could mobilize a great number of people towards achieving environmental sustainability in all kinds of socio-ecosystems. However, while social scientists and various groups of stakeholders may receive the idea of NBS well, its acceptance among natural scientists, in particular those involved in species and habitat conservation, remains a challenge as there is some distrust in "yet another buzz word" and concern that at the end these NBS may address biodiversity conservation only in a cosmetic manner, possibly generating even more pressure on natural systems.

For their successful deployment, we believe that NBS should not be considered as "the one and only" possible way, but need to be embedded in a wider, coherent strategy at research and policy level. Otherwise, NBS run the risk of misinterpretation, misapplication and non-acceptance. One of the risks is that it might channel all research and management efforts towards an approach that is useful in some but not all conditions, whereas nature preservation - and associated research - should be supported also.

The authors thank all the participants of the horizon scanning workshop organized in June 2014 by the BiodivERsA ERA-NET ${ }^{5}$. Various stakeholders (scientists, policy makers, non-governmental organizations, research programmers and funders) were asked to exchange their views on the emerging NBS term. The authors also thank Rachel Armstrong (University of Newcastle) for insightful discussion. BiodivERsA is the network of national and local organizations that program, fund, and promote pan-European research on biodiversity and ecosystem services. It was supported by the European Commission in the Seventh Framework Programme, and is further supported from 2015 under the ERA-NET cofund scheme in Horizon2020. First and last authors (Hilde Eggermont and Xavier Le Roux) contributed equally to this paper. 


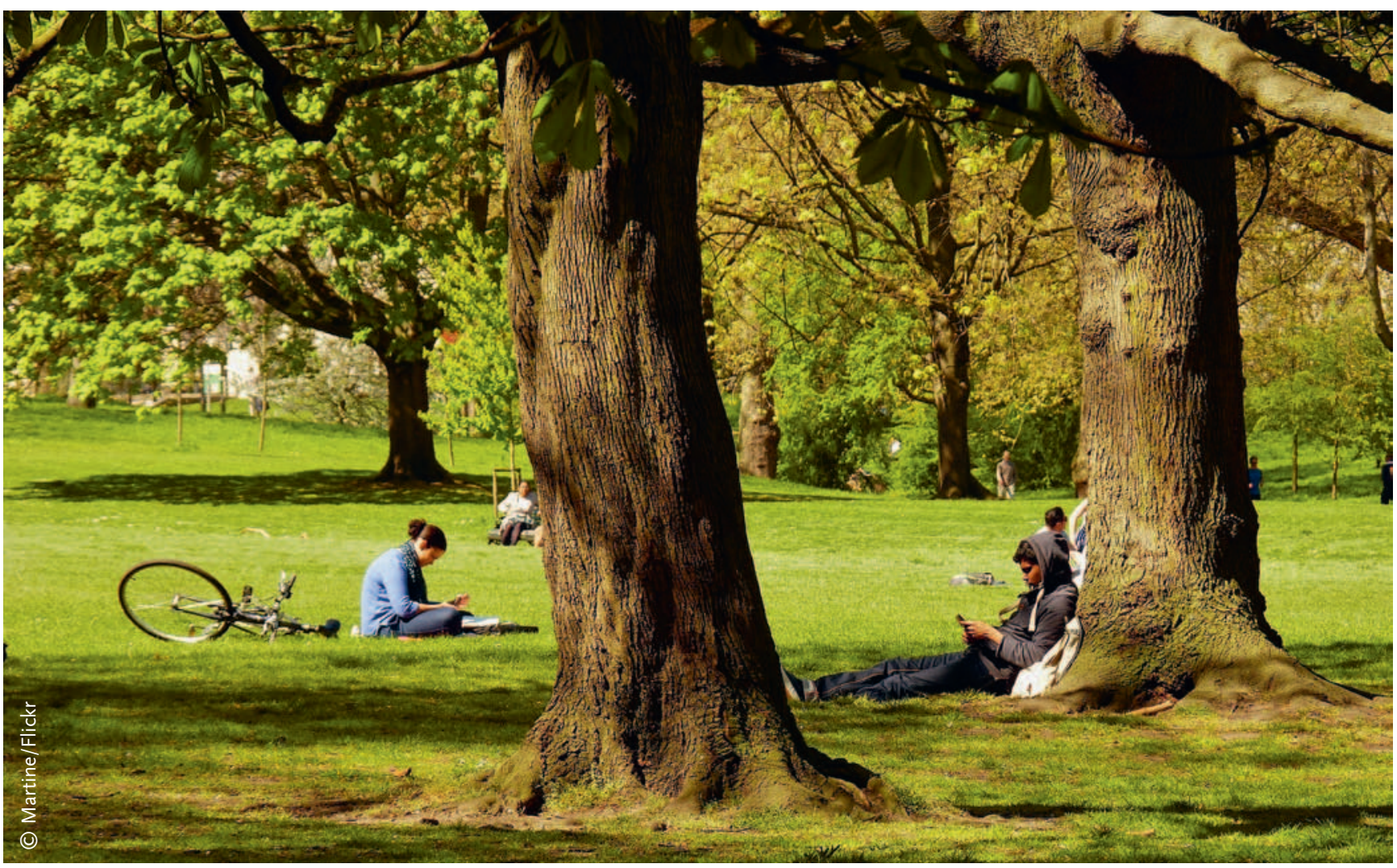

FIGURE 2: Nature-based solution approaches can promote the development and management of urban ecosystems to offer sustainable and cost-effective solutions to societal challenges like global warming, water regulation and human health, while enhancing biodiversity. Here, the Green Park in London.

\section{References}

Altieri, M.A. 1989. Agroecology - A new research and development paradigm for world agriculture. Agriculture, Ecosystems and Environment 27: 37-36.

Barot, S. et al. 2015. Evolving away from the linear model of research: A response to Courchamp et al. Trends in Ecology and Evolution 30: 368-370.

Barot, S., J. C. Lata, G. Lacroix. 2012. Meeting the relational challenge of ecological engineering within ecological sciences. Ecological Engineering 45: 13-23.

Benedict, M. A., E. T. McMahon. 2006. Green infrastructure: Linking landscapes and communities. Washington, D. C.: Island.

BIOMOT. 2014. Effective research for biodiversity action. Policy brief 3. www.biomot.eu/docs/BIOMOT\%20Policy\%20brief\%203.pdf (accessed October 7, 2015).

Borsje, B.W. et al. 2011. How ecological engineering can serve in coastal protection. Ecological Engineering 37/2: 113-122.

Burch, S, P. M. Berry, M. Sanders. 2014. Embedding climate change adaptation in biodiversity conservation: A case study of England. Environmental Science Q Policy 37: 79-90.

Costanza, R. et al. 1997. The value of the world's ecosystem services and natural capital. Nature 387: 253-260.

Cowan C., C. Epple, H. Korn, R. Schliep, J. Stadler (Eds.). 2010. Working with nature to tackle climate change. Report of the ENCA/BfN Workshop on "Developing ecosystem-based approaches to climate change - Why, what and how". Bonn: Bundesamt für Naturschutz (BfN). www.bfn.de/fileadmin/ MDB/documents/service/Skript264.pdf (accessed October 7, 2015).

Diaz, S. et al. 2015. The IPBES conceptual framework - Connecting nature and people. Current Opinion in Environmental Sustainability 14: 1-16.
Dudley, N. et al. 2010. Natural solutions: Protected areas helping people cope with climate change. Gland, CH: World Wide Fund For Nature (WWF). wwf.panda.org/about_our_earth/all_publications/?uNewsID=183021 (accessed October 7, 2015).

European Commission. 2015. Towards an EU Research and Innovation policy agenda for nature-based solutions Q $\mathrm{re-naturing} \mathrm{cities.} \mathrm{Final} \mathrm{Report} \mathrm{of} \mathrm{the}$ Horizon2020 expert group on nature-based solutions and re-naturing cities. Brussels: European Commission.

Garmestani, A. S., M. H. Benson. 2013. A framework for resilience-based governance of socio-ecological systems. Ecology and Society 18/1: Article 9.

Gómez-Baggethun, E., R. de Groot, P. L. Lomas, C. Montes. 2009. The history of ecosystem services in economic theory and practice: From early notions to markets and payment schemes. Ecological Economics 69: 1209-1218.

Grorud-Colvert, K. et al. 2014. Marine protected area networks: Assessing whether the whole is greater than the sum of its parts. PLOS ONE 9/8: e102298. doi:10.1371/journal.pone.0102298.

Hauck, J. et al. 2013. The promise of the ecosystem services concept for planning and decision-making. GAIA 22/4: 232-236.

Hauck, T. E., W. W. Weisser. 2015. AAD - Animal aided design. Freising: Technische Universität München. www.toek.wzw.tum.de/fileadmin/ 1_Datein/PDF_WWW/AAD_Broschuere_Webversion_10MB.pdf (accessed October 7, 2015).

Hoffert, M. I. et al. 2002. Advanced technology paths to global climate stability: Energy for a greenhouse planet. Science 298/5595: 981-987.

Howe, C., H. Suich, B. Vira, G. M. Mace. 2014. Creating win-win from trade-offs? Ecosystem services for human well-being: A meta-analysis of ecosystem service trade-offs and synergies in the real world. Global Environmental Change 28: $263-275$. 
IUCN (International Union for Conservation of Nature). 2009. No time to lose: Make full use of nature-based solutions in the post-2012 climate change regime. Position paper on the Fifteenth session of the Conference of the Parties to the United Nations Framework Convention on Climate Change (COP 15). Gland, $\mathrm{CH}$ : IUCN.

IUCN. 2012. The IUCN Programme 2013-2016. Gland, CH: IUCN. http://cmsdata.iucn.org/downloads/iucn_programme_2013_2016.pdf (accessed October 7, 2015).

Jackson, D. L. 2002. The farm as natural habitat: Reconnecting food systems with ecosystems. Washington, D. C.: Island.

Jones, C. 2011. Grand challenges for the future of ecological engineering. Ecological Engineering 45: 80-84.

Kareiva, P. 2014. New conservation: setting the record straight and finding common ground. Conservation Biology 28/3: 634-636.

Lefèvre, F. et al. 2014. Considering evolutionary processes in adaptive forestry. Annals of Forest Science 71: 723-739.

Lewinsohn, T. M. et al. 2015. Ecological literacy and beyond: problem-based learning for future professionals. Ambio 44: 154-162.

Lundholm, J., S. Tran, L. Gebert. 2015. Plant functional traits predict green roof ecosystem services. Environmental Science Q Technology 49: 2366-2374.

MacKinnon, K., N. Dudley, T. Sandwith. 2011. Natural solutions: Protected areas helping people to cope with climate change. Oryx 45/4: 461-462.

MacKinnon, K., V. Hickey. 2009. Nature-based solutions to climate change. Oryx 43/1: 13-16.

MacKinnon, K., C. Sobrevila, V. Hickey. 2008. Biodiversity, climate change and adaptation: Nature-based solutions from the Word Bank portfolio. Washington, D.C.: World Bank.

Millennium Ecosystem Assessment. 2005. Ecosystems and human well-being: Biodiversity synthesis. Washington, D. C.: World Resources Institute (WRI)

Mitsch, W.J. 2012. What is ecological engineering? Ecological Engineering 45: 5-12.

Mittermeier, R. et al. 2008. A climate for life: Meeting the global challenge. Arlington, VA: International League of Conservation Photographers.

National Research Council. 1992. Restoration of aquatic ecosystems. Washington, D.C.: National Academy Press.

Naumann, S. et al. 2011. Assessment of the potential of ecosystem-based approaches to climate change adaptation and mitigation in Europe. Final report to the European Commission, DG Environment. Berlin, Oxford, UK: Ecologic Institute, Environmental Change Institute, Oxford University Centre for the Environment.

Neßhöver, C. et al. 2013. Improving the science-policy interface of biodiversity research projects. GAIA 22/2: 99-103.

Primmer, E., E. Furman. 2012. Operationalising ecosystem service approaches specific knowledge systems? Ecosystem Services 1: 85-92.

Steffen, W. et al. 2015. Planetary boundaries: Guiding human development on a changing planet. Science 347/6223. doi:10.1126/science.1259855.

Teixeira, R., V. Proença, D. Crespo, T. Valada, T. Domingos. 2015. A conceptual framework for the analysis of engineered biodiverse pastures. Ecological Engineering 77: 85-97.

Submitted July 5, 2015; revised version accepted September 6, 2015. for governance: Do measuring, mapping and valuing integrate sector-

\section{CONTRIBUTING AUTHORS}

Dr. Hilde Eggermont, Estelle Balian, MSc Belgian Biodiversity Platform, Royal Belgian Institute of Natural Sciences, Brussels, Belgium

Dr. José Manuel N. Azevedo

Fundo Regional para a Ciência e Tecnologia, Açores, Portugal

Dr. Victor Beumer

Deltares, Delft, The Netherlands

Prof. Dr. Tomas Brodin

Umeå University, Department of Ecology and Environmental Science, Umeå, Sweden

Dr. Joachim Claudet

National Center for Scientific Research, CRIOBE, Perpignan, France

Dr. Bruno Fady

French Institute of Agronomic Research, Ecology of Mediterranean Forests, Avignon, France

Prof. Dr. Martin Grube Institute of Plant Sciences, University of Graz, Austria

Dr. Hans Keune

Belgian Biodiversity Platform, Research Institute for Nature and Forest,

Brussels, Belgium

Dr. Penelope Lamarque International Union for Conservation of Nature (IUCN), Gland, Switzerland

Dr. Katrin Reuter

Museum für Naturkunde Berlin - Leibniz Institute for Evolution and Biodiversity Science, Berlin, Germany

Matt Smith, MSc

Joint Nature Conservation Committee, Peterborough, United Kingdom

Chantal van Ham, MSc International Union for Conservation of Nature (IUCN), European Union Representative Office, Brussels, Belgium

Prof. Dr. Wolfgang W. Weisser Technische Universität München, Terrestrial Ecology Research Group, School of Life Sciences Weihenstephan, Freising, Germany

Dr. Xavier Le Roux

Microbial Ecology Center, French Institute of Agronomic Research, University Lyon 1, Lyon, France, and French Foundation for Research on Biodiversity, Paris, France

\section{Hilde Eggermont}

Born 1977 in Waregem, Belgium. MSc in biology, PhD in freshwater biology/paleolimnology. Scientific coordinator of the Belgian Biodiversity Platform and Vice-Chair of BiodivERsA ERA-NET. Research interests: science-policy and science-society interfacing, biodiversity, research strategies, horizon scanning.

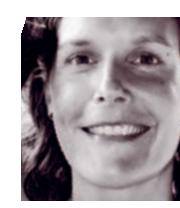

\section{Xavier Le Roux}

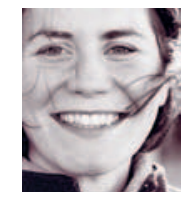

Born 1971 in Saint-Etienne, France. BA in genetics and molecular biology, MSc in fisheries and aquatic sciences. Biodiversity expert for the Belgian Biodiversity Platform. Competences in science-policy interfaces on biodiversity and ecosystem services at European and international levels, participatory processes, stakeholder engagement in scientific projects, facilitation and conflict resolution.
Born 1967 in Coutances, France. PhD in ecosystem ecology. Research team leader at the Microbial Ecology Centre of Lyon-Villeurbanne, Université Lyon. 2008 to 2012 director of the Foundation for Research on Biodiversity. Since 2008 coordinator and Chief Executive Officer of BiodivERsA

ERA-NET. Research interests: biodiversity, microbial ecology, research programming and promotion, science-society interfacing. 